\title{
Strengthening Roles of Pesantren in the Solving Problems Management of Covid 19
}

\author{
Fathimatuz Zahra \\ Sekolah Tinggi Agama Islam Pati \\ ima59114@yahoo.com
}

\begin{abstract}
Coronavirus 19, is a new virus that can infect anyone indiscriminately. This virus, not only as a virus that makes various layers of society experience anxiety, but also creates a point of introspection for all levels of society. In this process of mass introspection, pesantren has a strengthening role in order to provide peace to society and also as a source of community support in action. Because there are so many new regulations related to Covid 19 that are being debated in the religious field. This article will discuss the role of strengthening Islamic boarding schools in solving problems management of coronavirus 19. This research is a qualitative research by collecting library data and news related to the public's response to Covid 19. This article discusses the role of strengthening Islamic boarding schools in various problems related to Covid 19 in society. This researches findings using the theory of the role of reinforcement originating from pesantren which supports and has a significant impact on society. This research results in three problems of strengthening roles of pesantren in the solving problems management of coronavirus 19, there are based on fundamental thought Pesantren facing covid 19, Changing of religious rituals, and also roles of Islamic boarding schools in community spiritual strengthening. These three roles were parts of strengthening roles of pesantren in the societies in the solving problems management especially in the religious effects of the covid 19.
\end{abstract}

Keywords: Strengthening roles, pesantren, covid 19

\begin{abstract}
Abstrak
Coronavirus 19, merupakan virus baru yang bisa menginfeksi siapapun tanpa pandang bulu. Virus ini,tidak hanya sebagai sebuah virus yang membuat berbagai lapisan masyarakat mengalami kecemasan, namun juga membuat sebuah titik introspeksi seluruh lapisan masyarakat. Dalam proses introspeksi massal ini, pesantren memiliki peran penguatan agar dapat memberikan ketenangan terhadap masyarakat dan juga sebagai sebuah sumber topangan masyarakat dalam bertindak. Sebab banyak sekali aturan-aturan baru terkait covid 19 yang menjadi perdebatan dalam bidang keagamaan. Artikel ini akan membahas tentang bagaimana peran penguatan pesantren dalam manajemen penanganan covid 19 . Riset ini merupakan riset kualitatif dengan mengumpulkan data kepustakaan dan berita terkait respon masyarakat mengenai covid 19 ini. Artikel ini akan mendiskusikan mengenai bagaimana peran penguatan pesantren dalam berbagai problematika terkait covid 19 di masyarakat. Pertanyaan ini akan dijawab dengan menggunakan teori peranan penguatan berasal dari pesantren yang menunjang dan memberikan dampak signifikan di masyarakat.
\end{abstract}

Kata Kunci: Penguatan peran, pesantren, covid 19 


\section{Introduction}

Covid 19 is a virus that is indiscriminate about anyone. The big changes with the existence of Covid 19 make humans conduct an in-depth introspection of major changes in life in order to solve various problems that arise due to Covid 19(Olivia et al., 2020). These changes require the role and participation of thoughts from religious education institutions including pesantrens.

Pesantren have an important role in strengthening thinking in society, because most of our community groups are concerned about the Covid 19 problem and some religious rules that have become as unusual as before. This unusualness is because this virus has the main solution for physical distancing, in this case it means reducing the share of communality in religious rituals. The fundamental change in communal religious rituals has become distanced, moving the role of the pesantren as gatekeepers for the yellow book which incidentally is a source of reference for Islamic knowledge in various eras. It's not only happened in Indonesia but also in The Arab Saudi Cultures also (Al Lily et al., 2020).

Pesantren intellectualism once had a strong research tradition. The books of the archipelago's ulama have been circulating and have become important references in the Arabian Peninsula. Apart from being in the form of a book, there were also chapters, giant fibers, local wisdom, living history, with various themes and expressions. However, it is important to underline that these Nusantara works could not have been born without in-depth, diligent and long research. Mosque buildings that are very aesthetic are also impossible to be born without prior research (Muqoyyidin, 2014).

Therefore, to sustain the struggle, in the fields of knowledge, education, economics, politics, technology, culture, in a more optimal and transformative manner, pesantren must redistribute its long lost research power. According to Mustafied et al (2013: 5), with research, all pesantren activism will be based on valid data and research results. The need to develop strategic research within the pesantren environment is not only to answer external challenges, but also to 
optimize potential, multiply roles, and strengthen its position as a transformative force for the nation (Muqoyyidin, 2014).

As an educational institution that has typical characteristics, pesantren has a scientific tradition that is different from the scientific traditions of other institutions. When observed in the context of their educational activities, pesantren focuses more on tafaqquh fi diin namely deepening experience, expanding knowledge and mastering the treasures of Islamic teachings (Muqoyyidin, 2014).

As a tafaqquh fiddin institution, this institution studies and develops Islamic sciences (al-'ulm al-syar'iyyah). Teaching in this institution which is handled by scholars and kiai relies on the subject matter contained in the books that have been standardized in the Islamic world with traditions and disciplines that have been running continuously for centuries. Teaching has succeeded in shaping a moral and civilized society with different levels of intelligence, from students to 'alim (kiai and ustadz),' allamah and mujtahid. Although this may not have been realized so far, however, there is a fundamental differentiation between scientific manifestations in pesantren and scientific manifestations in other Islamic educational institutions throughout the Islamic world (Muqoyyidin, 2014).

The most striking characteristic of the pesantren tradition is a continuous network, lineage, sanad, or genealogy to determine the level of efisotericity and quality of an intellectual's ulema. This also distinguishes the intellectual tradition of the pesantren from the traditions in the campus environment, and even other Islamic educational institutions. In general, Islamic boarding schools are educational and teaching institutions of Islam in a non-classical way, in which a kiai teaches his students based on Arabic books written by major scholars in the middle ages (XII XVI centuries M). These books, both the books of matn, syarah\}, and h\} asyiyah are mu'tabarah books within the Ahlus Sunnah Wal Jamaah environment. These books, for example, Taqrib or Fathul al-Qarib, Safinat alNajjah, Sullam al-Tawfiq, al-Sittin Mas'alah, Minhaj al-Qawim, al-Hawasyi alMadaniyat, al-Iqna ', and Fath al-Muin. After the book is followed by a further book of fiqh, both in the form of an in-depth study of the material of ubudiyah worship and other materials. In the field of tauhid, the yellow books studied in Islamic boarding schools are generally Asy'ariyah 
thoughts which contain, among other things, obligatory characteristics (Muqoyyidin, 2014).

The emergence of fiqh sosial which was initiated by KH. MA. Sahal Mahfudh, exponent of pesantren and NU, is like a light in the middle of darkness that radiates an aura and spirit of optimism, confidence, and revitalization of classical treasures. In addition to exploring the meaning of religious texts (al-nushus al-diniyah), fiqh sosial also follows the development of contemporary reality, even guides, changes and encourages it systematically and continuously to conform to the religious spirit emitted by fiqh which has the essence of benefit, prosperity, justice, and prosperity (Asmani, 2016).

In this context, fiqh sosial is cultural fiqh, meaning fiqh that ignites the spirit of transformation, not just theory. Kiai Sahal is well known for his fiqh sosial, not just ideas, concepts, paradigms and theories, but also concrete evidence. It has social works, not just intellectual works. He carried out people's economic empowerment with the paradigm of fiqh sosial. He made fiqh as a basis for legitimacy and action in empowerment work. He combines organizational skills, relationship networking, management, leadership and charisma to roll the idea of fiqh sosial in the midst of the objective reality that surrounds him (Asmani, 2016).

Fiqh sosial's Kiai Sahal is the embryo of the birth of hadlori fiqh (fiqh of civilization). Fiqh which is capable of giving birth to a new, progressive, modern and productive civilization in producing intellectual and social works. In this context, the younger generation must be creative in continuing and developing the 'genuine' heritage thinking of Kiai Sahal. Fiqh sosial can be a mediator between two trends, liberalization and fundamentalization. Fiqh still stands on the text, but always sees reality in a transformative way (Asmani, 2016).

This researches using methods with media observatory researches, and also using researches virtual interview with the leaders of FKPPK and also neighborhood of the first Pesantren that infected covid 19 in Kajen areas. The research itself is an intervention because it seeks to promote actual change by informing and impacting a practice, procedure, system, or environment, thereby leading to the improvement of life for a desired targeted group of individuals. The strength of action research is 
indeed its focus on generating solutions to practical problems or issues and its ability to empower those working in practice-based environments by engaging them in the research process. As such, the most influential theoretical framework for action research is critical theory, as it aims to encourage and facilitate inclusion and active participation (Bloomberg \& Volpe, 2015) .

Researches about pesantren and covid 19 was written by any scholars, these are about preventive roles of leaders of Shaykh Zaitun in Ma'had Az-Zaytun, this researches was discussed about preventive roles(Prawoto et al., 2020). Other researches about management of pesantren in the covid pandemic 19 management, that was empowering all off potentiality on the natural resources such as farming, and also the non-physical management such as curriculum and etc (Kahfi \& Kasanova, 2020). And the third researches other was about studying in Pesantren in the covid 19 pandemics, this researches was bringing the solution that the transfer knowledges in the pesantren was pointed in the living Islam and learning together (Fahham, 2020). Based on three research above, this researches was has different perspectives of the solving problems management in the covid 19 pandemics in the pesantrens.

Based on basic scientific sources, Islamic boarding schools have strong scientific support in dealing with changes in Covid 19. With the latest concept of fiqh sosial which was initiated by Kiai Sahal, then the problems of changing times that arise as a result of various kinds of problems can be faced and solutions are sought.

\section{Based on Fundamental Thought Pesantren Facing Covid 19}

Covid 19 is a pandemic that has recently occurred and has caused changes in all people's lives. Pesantren is an educational institution with a high level of communality, so that during the Covid 19 pandemic it requires special handling so that it can face and pass the struggle during this pandemic properly.

Pesantren as the center of Islamic thought and the circulation of science in Indonesia. Indonesian Muslims even use different words for books in Romanized script 'buku' and those in Arabic script, irrespective of the language used 'kitab'. Up until the 1960's a well-defined line divided the Muslim community into 
'traditionalists' and 'modernists' (with as their major socio-religious organizations the Nahdlatul Ulama and the Muhammadiyah respectively) (Bruinessen, 1990).

The former used to study religion exclusively through kitab kuning (called kuning, 'yellow', after the tinted paper of books brought from the Middle East in the early twentieth century), while the latter read and wrote buku putih, 'white' books in Romanized Indonesian. The authors of buku putih usually rejected the greater part of the scholastic tradition in favour of a return to, and in some cases new interpretation of, the original sources - the Qur'an and the hadïth (Bruinessen, 1990).

This may have contributed to the negative attitude towards buku putih that existed in the pesantren milieu for many years - in a few old-fashioned pesantren such books are still prohibited until this day. Traditionalist ulama writing books or brochures, whether in Arabic or in one of the vernacular languages, always used the Arabic script, and many of them continue to do so (Bruinessen, 1990).

Nowadays, however, the dividing line between 'modernists' and 'traditionalists' no longer is so sharp and clear, and many of the old antagonisms have worn off. The 'modernists' have generally become less radical in their rejection of tradition - significantly, there are now several Muhammadiyah pesantren offering a combination of the traditional curriculum (kitab kuning) and that of the modern school. Not only have most 'traditionalist' kyai, on the other hand, become more catholic in their reading, but many of them now write in Indonesian as well as in Arabic, Malay or Javanese (Bruinessen, 1990).

The Arabic script, though still the most unambiguous sign of a traditionalist orientation, is no longer a sine qua non for it. I have not therefore applied the criterion of script too rigidly, and have included in the collection under discussion a number of works in (Romanized) Indonesian which logically belong to the kitab tradition, being annotated translations of, or commentaries on, classical texts by 'traditionalist' ulama(Bruinessen, 1990).

This manuscripts was important as a reference when the Covid 19 pandemic hits Indonesia. This is because there are so many communal rituals that must be changed in accordance with the procedures for implementing Covid 19 "physical 
distancing". Here flexibility is needed but with a strong reference base in tackling Covid 19. This methods of Fiqh Sosial was parts of religiosity influences prosocial behaviour in a number of ways. Prosocial behaviour may be defined analytically as 'Behavior carried out for the benefit of others', such as giving donation to charity, helping a stranger by giving directions in town or saving somebody from drowning. Prosocial behaviour is a multidimensional construct. Penner, Fritzsche, Craiger, and Freifeld (1995) described factors which are responsible for prosocial behaviour and developed 'Prosocial Personality Battery'(Kaur, 2020).

The link between religiosity and prosocial behaviour is explained by 'supernatural punishment hypothesis' and 'costly signaling theory'. According to the supernatural punishment hypothesis, cooperation among the members of the large group is maintained by the perceived presence of God. Religious prosociality also explained by 'costly signaling theory', which suggests that religious commitments are used as costly signalling device. Studies have shown that religiosity leads to prosocial behaviour (Kaur, 2020). This prosocial religiosity messages that brings of Fiqh sosial souls.

The discovery of the concept of Thaun (plague) during the time of the prophet and its handling at that time first appeared on the social media of the Pesantren Mansajul Ulum. Based on this first clue, then the figures and scholars who have a concern on this yellow book then formulate the procedures for worship during this pandemic period based on the study of various books (Ashraf et al., 2020).

\section{Changes in Religious Rituals}

Some of the problems experienced by society are: the implementation of routine congregational prayers, tarawih prayers, and holiday prayers; and a complete guide to Ramadan and Eid al-Fitr during the Corona pandemic, as stated in Circular Number 6 of 2020 issued by the Ministry of Religion. Both of two problems, in society was parts of discussion and recognition of the burgeoning virtual congregations for online religion, and the vocabulary that attends them, resonate with a lexicon of community, familiarity, joining together, connected, one body, and the people of God. This is much more than an upsurge in spontaneous 
religiosity brought about by fear and isolation. Rather, it is something that creates (and is created by) ashifting understanding of the relationship between a religious community that is locally defined as a communion of believers, and in which relationships are already established, and the experience of an online virtual community that humanises in a time of isolation but also relies on bonds that may not be embodied in the physical world(Parish, 2020). This problems makes intersections between ulama, community, Islamic symbols in societies discussion.

The differentiation rules in the Ramadhan before covid 19 was very striking, its automatically makes the stronger differentiation. All of the rules of Ramadhan makes cultural difference in the Moslem Ramadhan congregation, it can effects peoples get the suffering because of this differentiation. When incidents of suffering occur, people naturally attempt to interpret and understand them; and the way people construe and think about suffering tends to be shaped by their cultural worldviews (Ji et al., 2020).

The handling of the bodies of victims of Covid 19 is also a problematic dilemma in Indonesian society. Various rejections emerged, even to the point that there were families who forced to open and purify the bodies of Covid victims without paying attention to the risks they would get.

The development of this rule in the case of the rejection of a corpse infected by Covid 19 is, clearly that it is a dangerous virus that can threaten a person's life. However, the preventive action by carrying out the act of rejection is also a separate danger and detrimental to various parties, especially victims and their families. Moreover, supported by medical statements about the death of virus along with the death of its host, as well as the implementation of a funeral process that still uses medical protocols(Labib, 2020).

Based on this guideline, taking precautions to prevent the transmission of the Covid19 virus by rejection is not justified and is not in accordance with medical facts and Islamic legal norms. Maqasid syaria becomes an important entity to develop Islamic law trough fiqh sosial theory, explicitly presented as the basis as well as the direction of the provisions of a law, in controlling the demands 
for openness thought in cross-disciplinary disciplines, while at the same time Its function isto avoid interests and egocentrism (Labib, 2020).

Referring to the results of the analysis above with the model of the madzhab qauli of fiqh sosial, the conclusions narrowed to the statement that the rejection of the corpse infected by Covid 19 in Banyumas, Lampung, Gowa, and Semarang, is an action that is not justified according to Islamic legal norms. Fortesting whether the product or the results of excavation of Islamic law are in harmony with the benefit that is the goal of the Islamic religion, then maqasid syaria is presented. Specifically, among the various types of maqashid syaria, the type of hifdzu al karamah al insaniyyah (maintaining human glory) according to Abdul Majid Najjar which is a branch of the general concept of hifdzu an-nafs(protecting life) is very relevant as the initial foothold, the direction law, as well as legal control.

The corpse infected by Covid 19 which was declared as "syahid akhira", or even if there were no such claims, received a respectable view of Islam. That is because the glory of man has been carried since he was created, without any frills, and remained until he died. The final form of respect for the glory or honor that human beings -in this case -is the body of Covid 19, is to take care and to handle according to Islamic legal norms. Therefore, based on the basic principles of maqashid hifdzu al karamah al insaniyyah, the "unjustified" claim of the rejection of the corpse infected by Covid 19 was extracted from 3 authoritative opinions of ulama', as well as 2 types of fiqh rules above, considered as a product of Islamic law that had been in harmony with maqashid syaria (Labib, 2020).

Such a tradition of collective religious rituals that has been going on for centuries, in the era of the Covid-19 disaster like now, has experienced a significant and surprising change in shape. Religious orders to carry out worship collectively or in congregation, especially in public spaces, have been temporarily reduced or completely frozen for an uncertain period. Religious responses are generally preoccupied with the interpretation of religious texts, whether derived from the Scriptures or other authoritative texts.

In Islamic history, differences in attitudes in dealing with epidemic situations can be found in various hadith literature, especially the story of Umar bin Khattab 
who failed to visit because the area to be visited was hit by the plague. Imam alGhazali in "Ihya Ulumuddin" wrote this history, in which he mentioned that Umar, after arriving at al-Jabiyyah - an area near Damascus - when he was going to Syria, received news that Syria was being hit by a deadly disease outbreak.

This news has led to two groups of disagreements: those who believe that they must avoid destruction so they must return and others continue their journey, believing that God's destiny should not be avoided, except with patience and tawakal. Then, what about Umar? It appears that the Caliph is more moderate: he does not continue his journey by reason of himself avoiding one destiny to go to another better destiny of God. Meanwhile, the region that is suspected of spreading the plague for the first time has declared itself free from the pandemic.

Looking at the various literatures written by Muslim scholars - one of which is quite well written by Ibn Hajar al-Asqallani: "Badzlu al-Ma'un fi Fadhl at-Tha'un" - it is almost certain that the plague is related to physical and physical matters. metaphysical, so that the plague is related to God's punishment of a certain people or infectious disease which physically appears and will in a certain time end by itself. That is why, that a hadith in the history of Muslims mentions where the Prophet stated, "Don't you enter an area affected by the plague, but if you happen to be in it, don't run away from that area".

Sometimes, the above hadith concludes or is used as a "justification" for the condition "don't go to the red zone of the plague, just stay at home". At first glance this assumption seems correct, even though in reality what is categorized as a red, green, or yellow zone seems absurd and tends to be viewed the same by many. As a result, problems arise in the midst of the reality of the Muslim community, especially in the context of communal rituals that are prohibited or restricted, even though their territory is called a green zone that is relatively free of the COVID-19 outbreak. So far, various policies regarding pandemic conditions - to a certain extent - are indeed contrasting, especially when comparing the handling of the epidemic in Muslim countries which is also related to religious policies and at the same time the conditions for handling them are different as those carried out in various Western countries. 
The concepts of plague (tha'un) from a religious perspective, especially Islam, given that there have been a series of incidents of restricting Muslim worship, including the closure of mosques and the prohibition of Friday prayers or certain prayers that involve large numbers of people. In many Muslim-majority countries, religious authorities have issued fatwas explicitly "prohibiting" communal worship, including carrying out "closing" of mosques.

As we can see from the fatwa of Sheikh Abdullah bin Bayyah from the UAE or Dar al-Ifta Egypt, which had earlier obliged to temporarily close mosques and eliminate Friday prayers or other communal worship. Although there are also different perspectives from other scholars who reject the closure of places of worship and limit their spirituality in any context, as proposed by Sheikh Hakim alMathiri who was later followed by several Muslim countries such as Syria and Kuwait. Disagreements like this of course occur in Indonesia, however, the MUI fatwa officially responds to this difference, by not prohibiting worship in congregations or wearing them in order to close mosques.

It is interesting when looking at the MUI Fatwa No. 14 of 2020 concerning "Organizing Worship in a Situation of the COVID-19 Outbreak" which regulates and limits Muslim worship in the midst of a pandemic outbreak. The argument of this MUI fatwa has fulfilled a process of extracting the sources of Islamic law which can become a legal basis, in which there is no mention of closing mosques or prohibiting Friday prayers or congregations taking into account certain conditions. In its legal provisions, especially in dictum number 3 point $b$, it states, "In the event that he is in an area where the potential for transmission is low based on the provisions of the authorities, he is still obliged to perform worship as usual and must guard himself so as not to be exposed to Covid-19 ..." . This dictum contains an explanation of the substance of the law imposed from legal arguments (adillatu al-ahkam) which are religious considerations, especially regarding worship during the outbreak.

The changing of religious rituals automatically makes the effects in the societies. These effects are problems of prosocial religiosity, problems of hopefulness and also problems of trauma. Hundreds of thousands of people have died and millions of cases have been reported worldwide in the COVID-19 pandemic 
(Washington Post, 2020). In addition to health aspects, the COVID-19 crisis has had social, economic, and developmental consequences, and policy measures are needed both to contain the pandemic and to mitigate the wider social consequences.

Indeed, in many countries, "health systems are weak, governments have little financial flexibility, and the majority of populations are not protected by social safety nets, making sickness, unemployment, and loss of wages in these circumstances even more problematic" (GPF, 2020). It must be supported by individual level (knowledge, attitudes/beliefs, and skills), family and community level (friends and social networks), Institutional level (relationships among organizations), systemic level (national, state, and local policies, laws, and regulations) (McNeely et al., 2020).

\section{The roles of Islamic boarding schools in community spiritual strengthening}

In the context of a religious society like Indonesia, we will of course get various theological questions regarding this pandemic which revolves around, is this plague a divine will, so that we are required to surrender or actually rise up against it? Is this plague closely related to God's punishment or is it His grace? Does this epidemic involve anything metaphysical or is it the result of a virus whose origins can be identified which is completely separate from occult matters?

Seeing the varied impact of the globalization era on Islamic Education, Islamic Education actually has quite a tough challenge in facing and protecting students from its negative effects. Those challenges include first is challenges in cultural, ethical and moral field as a result of technological advances in transportation and information; second is the global and free trade enactment meaning that the graduates face tight work competitions; third is from international surveys; the surveys indicated that the education quality in Indonesia is low or even rank as bottom position compared to neighboring countries; and fourth is low social capital problem which essentially from trust (trust attitude) (Tolchah \& Mu'ammar, 2019).

Pesantren is a traditional Islamic educational institution led by the kiyai (Siregar, 2013). In pesantren, the students are exposed to various branches of 
religious knowledge usually derived from kitab kuning (yellow books) which become classical texts and references in their Islamic and religious education. Apart from that, understanding and memorization of the Qur'an and the Hadith is necessary for the students (Nor \& Malim, 2014).

Opening of learning activities in Islamic boarding schools at the time of Covid19 pandemic was interesting, because of pesantren was a islamic boarding school education in which the students live in a continuous process of interaction. The capacity of boarding schools' dormitories is generally limited, the facilities for bathing, washing and latrines are publics area, and the quantity of pesantren environmental sanitation is also limited. With all these limitations, it is feared that pesantren will become a new cluster for the spread of Covid-19. Especially until mid of July 2020, the spread of Covid-19 was found in several Islamic boarding schools, including: Al Fatah Temboro in Magetan, Gontor in Ponorogo, Sempon in Wonogiri, and Islamic boarding schools in Tangerang City and Pandeglang, Banten Province (regional.kompas.com, 11 July 2020) (Fahham, 2020).

In the covid pandemic solving management pesantren makes the system resiliences, Organizational resilience is known to have three interconnected levels: (i) the individual level, for example, individual students of Islamic boarding school who use workarounds to temporarily resolve recurring safety problems on the frontlines, and then communicate their safety concerns to managers, in an effort to prevent problem recurrence; (ii) the team level, for example, Covid 19 centre who encourage frontline students of Islamic boarding school to freely communicate their safety concerns, with a view to addressing underlying issues and preventing problem recurrence; and (iii) the organizational level, for example, senior leadership commitment to patient safety and lasting improvement (change) (Rangachari \& Woods, 2020).

Within the continuing increase of the COVID-19 case, the Indonesian government plans to implement a new normal policy. New normal is a change of behavior to keep running normal activities during the pandemic. There are three indicators that must be obeyed by every region in Indonesia during the new normal period, namely: 1) not increasing transmission, expanding transmission or reducing 
transmission to the maximum extent; 2) using health system indicators, which measure how high the adaptation and capacity of the health system can respond to COVID-19 services and 3) Surveillance is a way to test a person or group of people whether he has the potential to have COVID-19 or not so that a massive test (Setkab, 2020). The new normal policy is also planed for education sector, and the government is currently preparing regulations for it (Sujadi et al., 2020).

Organizations detached from a traditional, effective-based hierarchical model toward nurturing the culture of flexibility, agility, and resilience find it easier to adapt to changes and reorganize their resources in times of crisis. Enterprises with a more loose and adaptive business model are quick to reduce stressors and adjust. They are characterized by diversity and maneuverability, and this plasticity allows them to reshuffle their priorities and proceed with emergent activities during risks. This study finds that organizations favouring adaptive culture are more likely to sustain business operations during the pandemic. Furthermore, resilient organizations allow for more informed and decentralized decision-making (Obrenovic et al., 2020). It's also that used by Islamic boarding school for preventing covid 19 infected in this area.

And most importantly, perhaps, is there a common law that can be used to tackle the epidemic, regardless of individual beliefs which differ across countries? In the context of globalization, an outbreak that was initially endemic and then became a pandemic is a necessity, but in reality the way of handling its spread appears to be not uniform in various affected areas.This shows the important role of Islamic boarding schools in the Covid 19 era as an indicator of the strength of community resilience in dealing with the Covid 19 outbreak and its various problems.

\section{Conclusion}

Covid 19 is a change and order and it is inevitable to add knowledge for mankind. Islamic boarding schools as one of the centers of religious civilization appear to have an increasingly important role in community life and become the center of solutions for community solutions. The strengthening roles of pesantren 
of solving problems management of coronavirus 19 was contains of three parts firstly based on fundamental thought pesantren facing Covid 19, secondly was roles in the societies when religious rituals changing and third was roles of Islamic boarding schools in community spiritual strengthening.

\section{References}

Al Lily, A. E., Ismail, A. F., Abunasser, F. M., \& Alhajhoj Alqahtani, R. H. (2020). Distance education as a response to pandemics: Coronavirus and Arab culture. Technology in Society, 63(1). https://doi.org/10.1016/j.techsoc.2020.101317

Ashraf, H., Faraz, A., Raihan, M., \& Kalra, S. (2020). Fighting pandemics: Inspiration from Islam. Journal of the Pakistan Medical Association, 70(5). https://doi.org/10.5455/JPMA.34

Asmani, J. M. (2016). Fiqh Sosial Kiai Sahal sebagai Fiqh Peradaban. Wahana Akademika: Jurnal Studi Islam Dan Sosial, 2(2). https://doi.org/10.21580/wa.v2i2.390

Bloomberg, L. D., \& Volpe, M. F. (2015). A complete dissertation: The big picture. Completing Your Qualitative Dissertation: A Road Map from Beginning to End.

Bruinessen, M. (1990). Kitab kuning; Books in Arabic script used in the Pesantren milieu; Comments on a new collection in the KITLV Library. Bijdragen Tot de Taal-, Land-En Volkenkunde / Journal of the Humanities and Social Sciences of Southeast Asia. https://doi.org/10.1163/22134379-90003218

Fahham, A. M. (2020). Pembelajaran di Pesantren pada Masa Pandemi Covid-19. Pusat Penelitian Badan Keahlian DPR RI.

Ji, L. J., Khei, M., Yap, S., Wang, X., Zhang, Z., \& Hou, Y. (2020). Cultural Differences in the Construal of Suffering and the COVID-19 Pandemic. Social Psychological and Personality Science. https://doi.org/10.1177/1948550620958807

Kahfi, S., \& Kasanova, R. (2020). Manajemen Pondok Pesantren di Masa Pandemi Covid-19 (Studi Pondok Pesantren Mambaul Ulum Kedungadem Bojonegoro). Pendekar: Jurnal Pendidikan Berkarakter, 3(1). https://doi.org/https://doi.org/10.31764/pendekar.v3i1.2827

Kaur, S. (2020). Effect of Religiosity and Moral Identity Internalization on Prosocial Behaviour. Journal of Human Values, 26(2), 186-198. https://doi.org/10.1177/0971685820901402

Labib, M. (2020). Analyzing Rejection of Corpse Infected by Covid 19 in the Perspective of Moral Panic and Fiqh Sosial Theories. Santri: Journal of Pesantren and Fiqh Sosial, 1(1). https://doi.org/10.35878/santri.v1i1.199 
McNeely, C. L., Schintler, L. A., \& Stabile, B. (2020). Social Determinants and COVID19 Disparities: Differential Pandemic Effects and Dynamics. World Medical and Health Policy, 12(3). https://doi.org/10.1002/wmh3.370

Muqoyyidin, A. W. (2014). Kitab Kuning dan Tradisi Riset Pesantren di Nusantara. IBDA': Jurnal Kajian Islam Dan Budaya, 12(2), 119-136. https://doi.org/10.24090/ibda.v12i2.441

Nor, M. R. M., \& Malim, M. (2014). Revisiting islamic education: The case of Indonesia. Journal for Multicultural Education, 8(4), 261-276. https://doi.org/10.1108/JME-05-2014-0019

Obrenovic, B., Du, J., Godinic, D., Tsoy, D., Khan, M. A. S., \& Jakhongirov, I. (2020). Sustaining enterprise operations and productivity during the COVID-19 pandemic: "Enterprise effectiveness and sustainability model." Sustainability (Switzerland). https://doi.org/10.3390/su12155981

Olivia, S., Gibson, J., \& Nasrudin, R. (2020). Indonesia in the Time of Covid-19. Bulletin of Indonesian Economic Studies, 56(2), 143-174. https://doi.org/10.1080/00074918.2020.1798581

Parish, H. (2020). The absence of presence and the presence of absence: social distancing, sacraments, and the virtual religious community during the covid19 pandemic. Religions, 11(6), 276. https://doi.org/10.3390/rel11060276

Prawoto, I., Rohmah, S. N., \& Sunarya, F. R. (2020). Peran Preventif Pemimpin Dalam Pencegahan Penyebaran COVID-19; Strategi Syaykh Al-Zaytun di Ma'had Al-Zaytun dan Kontribusinya Terhadap Masyarakat Sekitar. SALAM: Jurnal Sosial Dan Budaya Syar-I, 7(5). https://doi.org/10.15408/sjsbs.v7i5.15571

Rangachari, P., \& Woods, J. L. (2020). Preserving organizational resilience, patient safety, and staff retention during covid-19 requires a holistic consideration of the psychological safety of healthcare workers. International Journal of Environmental Research and Public Health, 17(12), 4267. https://doi.org/10.3390/ijerph17124267

Sujadi, E., Fadhli, M., Kamil, D., Ridha DS, M., Sonafist, Y., Meditamar, M. O., \& Ahmad, B. (2020). An anxiety analysis of educators, students and parents facing the new normal era in education sector in indonesia. Asian Journal of Psychiatry, 53. https://doi.org/10.1016/j.ajp.2020.102226

Tolchah, M., \& Mu'ammar, M. A. (2019). Islamic education in the globalization era; challenges, opportunities, and contribution of islamic education in indonesia. Humanities and Social Sciences Reviews, 7(4). https://doi.org/10.18510/hssr.2019.74141 